CASE REPORT

\title{
The dipsomania of great distance: water intoxication in an Ironman triathlete
}

\author{
T D Noakes, K Sharwood, M Collins, D R Perkins
}

Br J Sports Med 2004;38:e16 (http://www.bjsportmed.com/cgi/content/full/38/4/e16). doi: 10.1136/bjsm.2003.004614

Of 371 athletes (62\% of all finishers) whose weights were measured before and after the $226 \mathrm{~km}$ South African Ironman Triathlon, the athlete who gained the most weight $(3.6 \mathrm{~kg})$ during the race was the only competitor to develop symptomatic hyponatraemia. During recovery, he excreted an excess of 4.6 litres of urine. This case report again confirms that symptomatic hyponatraemia is caused by considerable fluid overload independent of appreciable $\mathrm{NaCl}$ losses. Hence prevention of the condition requires that athletes be warned not to drink excessively large volumes of fluid (dipsomania) during very prolonged exercise. This case report also shows that there is a delayed diuresis in this condition and that it is not caused by renal failure.

$\mathrm{T}$ he symptomatic hyponatraemia of exercise has been recognised more and more often since its first description in $1985^{1}$ and $1986 .^{2}$ A recent review ${ }^{3}$ details 57 cases, many severe, that have since been reported, mostly in ultraendurance athletes. Not included in that review are 26 additional cases from the 1998 and 1999 San Diego $42 \mathrm{~km}$ standard marathons alone, ${ }^{4}$ a further 21 cases from the 2000 Houston Marathon, ${ }^{5}$ and an estimated 19 cases a year between 1989 and 1999 in the United States Military. ${ }^{6-9}$ At least four athletes or military recruits have died from this condition; all reported deaths have occurred in the United States. ${ }^{67^{9-11}}$ Such deaths are particularly regrettable if they occur in athletes or military personnel who began the fatal exercise bout in apparently perfect health. Two contrasting theories have been proposed to explain this novel phenomenon.

Whereas some have consistently proposed that the condition cannot occur in the absence of a substantial fluid overload to which the usual $\mathrm{Na}^{+}$deficit incurred during exercise plays an insignificant role, ${ }^{12-22}$ others have conjectured that the condition occurs either in dehydrated runners who have incurred sufficiently large $\mathrm{Na}^{+}$deficits, ${ }^{23-27}$ or, alternatively, that "both large salt losses via sweat and excessive water intake, singly or in combination, contribute to lowering serum $\mathrm{Na}^{+}$during prolonged exercise" ${ }^{\prime 8}$ As argued previously, ${ }^{14}{ }^{28}$ the current guidelines of the American College of Sports Medicine (ACSM) favour the latter interpretation because the ACSM position stands on heat and cold illnesses during distance running ${ }^{29}$ and on exercise and fluid replacement ${ }^{30}$ both promote the practice of $\mathrm{Na}^{+}$ replacement during exercise to prevent hyponatraemia but fail to mention any possible dangers associated with excessive fluid consumption.

In the face of such continuing uncertainty, we report a further case study that confirms certain important causative factors and management principles for this potentially fatal condition. The data support the argument that this condition is both foreseeable and preventable and results from a specific, relatively recent paradigm shift in the drinking advice given to athletes participating in endurance events. ${ }^{13} 31-33$

\section{CASE REPORT}

A 34 year old experienced ultramarathon runner (numerous $42 \mathrm{~km}$ marathons: best time 03:30; $8 \times 90 \mathrm{~km}$ Comrades Marathon: best time 09:13:00; $12 \times 56 \mathrm{~km}$ ultramarathons; 4 $\times 180 \mathrm{~km}$ ultratriathlons: best time 07:13:00) competed in his first $226 \mathrm{~km}$ Ironman triathlon in Gordon's Bay, Cape Town, South Africa on 31 March 2001. Air temperature during the race ranged from $15.6^{\circ} \mathrm{C}$ to $20.9^{\circ} \mathrm{C}$ with a midday value of $20^{\circ} \mathrm{C}$ and an average value of $17.2^{\circ} \mathrm{C}$. Average humidity was $63 \%$ with a maximum value of $79 \%$ and a minimum value of $48 \%$. Sea temperature was $15^{\circ} \mathrm{C}$. Average wind speed was $6.4 \mathrm{~m} / \mathrm{s}$ with a maximum gust of $22.3 \mathrm{~m} / \mathrm{s}$ $(81 \mathrm{~km} / \mathrm{h})$ at $851 \mathrm{pm}$. Before the race the subject participated in a research study in which he was weighed three days before $(80.0 \mathrm{~kg})$ and on the morning of $(81.7 \mathrm{~kg})$ the race. A blood sample was also drawn three days before the race for measurement of serum electrolyte concentrations, which were normal (serum $\left[\mathrm{Na}^{+}\right]$ $143 \mathrm{mmol} / \mathrm{l}$, serum $\left.\left[\mathrm{K}^{+}\right] 4.0 \mathrm{mmol} / \mathrm{l}\right)$ as were serum urea ( $4.9 \mathrm{mmol} / \mathrm{l})$ and creatinine $(103 \mu \mathrm{mol} / \mathrm{l})$ concentrations. The laboratory methods used in these analyses have previously been described. ${ }^{12}{ }^{34}$ Before the race, the athlete volunteered to participate in a study to determine the effects of $\mathrm{Na}^{+}$ supplementation during prolonged exercise. He was part of the placebo leg of the trial. He was given starch-containing tablets (250 mg starch in each) and advised to ingest four to eight an hour for the duration of the race.

The athlete completed the race in 12 hours 23 minutes and 11 seconds (swim 1:07:26; cycle 6:31:38; run 4:44:07) and was brought to the medical tent $20 \mathrm{~m}$ from the race finish in the company of his wife. He was mildly confused, complaining that he felt unwell. He had difficulty concentrating and was unable to sustain a conversation, becoming sleepy when not addressed directly. His wife volunteered that his face was "swollen." His weight measured on admission to the medical tent was $85.5 \mathrm{~kg}$, indicating an absolute weight gain during the race of $3.8 \mathrm{~kg}$. As about $800 \mathrm{~g}$ fuel is oxidised during an Ironman triathlon with the release of perhaps a further $1 \mathrm{~kg}$ fluid ${ }^{1720}$, the total fluid excess at the race finish would probably have been at least $5 \mathrm{~kg}$.

Clinical examination of his fluid status showed that he was still actively sweating, he was able to produce saliva, his skin turgor was normal, and his eyes were not sunken. He had visible oedema of the hands and face and his wedding ring was tighter than usual. There was no other evidence of generalised oedema. His blood pressure in the supine position was 90/65 mm Hg, and his pulse was 92 and regular. Blood pressure was not measured in the standing position because of the high probability that the patient would faint from postural hypotension. The jugular venous pressure was not raised. Auscultation of the heart did not reveal any added 
sounds. There were no pulmonary rales on auscultation of the lung bases.

Immediate blood analysis using conventional methods ${ }^{12} 34$ revealed a serum $\left[\mathrm{Na}^{+}\right]$of $127 \mathrm{mmol} / \mathrm{l}$, serum $\left[\mathrm{K}^{+}\right] 5.8 \mathrm{mmol} /$ l, blood [glucose] $5.8 \mathrm{mmol} / \mathrm{l}$, serum [urea] $6.4 \mathrm{mmol} / \mathrm{l}$, and serum [creatinine] $98 \mu \mathrm{mol} / \mathrm{l}$; the latter two values were unchanged from before the race. A diagnosis of uncomplicated fluid overload hyponatraemia with post-exercise hypotension was made, and the patient was nursed in the head down position with the foot of the bed raised, our standard method for the treatment of hypotension. ${ }^{33}{ }^{35}$ We concluded that his state of hypotension despite fluid overload was due to a low peripheral vascular resistance.

He was placed on no fluids by mouth but was given an additional $16 \mathrm{NaCl}$ tablets, each containing $250 \mathrm{mg} \mathrm{Na}^{+}$to be ingested over the next following four hours. Management was expectant, awaiting a natural diuresis to correct the state of self induced water intoxication.

During the next four hours, despite frequent encouragement to empty his bladder, the patient passed urine only twice with a total volume of about $500 \mathrm{ml}$. The urine was a straw colour. His condition was otherwise unchanged, and his serum $\left[\mathrm{Na}^{+}\right]$fell marginally to $125 \mathrm{mmol} / \mathrm{l}$. As he was the sole remaining patient in the medical tent at the end of the race at midnight, he was transferred by ambulance to the nearest hospital where he was given $50 \mathrm{mg}$ furosemide intramuscularly on admission. Overnight he passed a further 4.1 litres of urine and was discharged from hospital at midday the following day, fully recovered, with a normal serum $\left[\mathrm{Na}^{+}\right]$concentration $(136 \mathrm{mmol} / \mathrm{l})$. He did not receive any intravenous fluids in hospital, and only after his serum $\mathrm{Na}^{+}$concentration had normalised was he again allowed to ingest fluids.

Subsequent analysis of the first urine sample passed by the athlete one hour after he finished the race showed $\left[\mathrm{Na}^{+}\right]$ $46 \mathrm{mmol} / \mathrm{l},\left[\mathrm{K}^{+}\right.$] $86 \mathrm{mmol} / \mathrm{l}$, [urea] $69 \mathrm{mmol} / \mathrm{l}$, and [creatinine] $10.8 \mu \mathrm{mol} / \mathrm{l}$. Later questioning revealed that he had ingested about $750 \mathrm{ml} / \mathrm{h}$ during the cycle leg but that in the first $3 \mathrm{~km}$ of the run he had ingested $750 \mathrm{ml}$ where after he began to drink "as much as possible" as he felt poorly and assumed this was due to dehydration. This practice was the exact opposite of the advice given to the athletes in the briefing before the race. He ingested water, Coca Cola, and a sports drink, as well as energy bars and a high energy meal replacement solution.

As most of the data had been collected routinely for most of the triathletes in that race as was the case in the 2000 race, ${ }^{36}$ it is possible also to compare this athlete's fluid status after the race with that measured in other triathletes who were not similarly affected.

Figure 1A shows the relation between changes in serum $\left[\mathrm{Na}^{+}\right]$and body weight in the 371 athletes $(62 \%$ of all finishers) whose body weights were measured before and after the race. These data show an inverse relation between serum $\left[\mathrm{Na}^{+}\right]$and percentage change in body weight during the race, so that athletes who lost the most weight during the race and hence were the most dehydrated had the highest serum $\left[\mathrm{Na}^{+}\right]$after the race, as has repeatedly been shown. ${ }^{13} 1718203637$

More significantly, this athlete (arrowed in fig lA) gained the most weight during the race and was the only athlete also to have a serum $\left[\mathrm{Na}^{+}\right]$below $130 \mathrm{mmol} / \mathrm{l}$. All athletes, both finishers and non-finishers, were medically examined after the race, and blood samples were taken if there was any doubt about the possible clinical diagnosis. We are therefore absolutely certain that he was the only athlete in the race to develop symptomatic hyponatraemia. Furthermore a subsequent check of all hospitals in the area revealed that no other
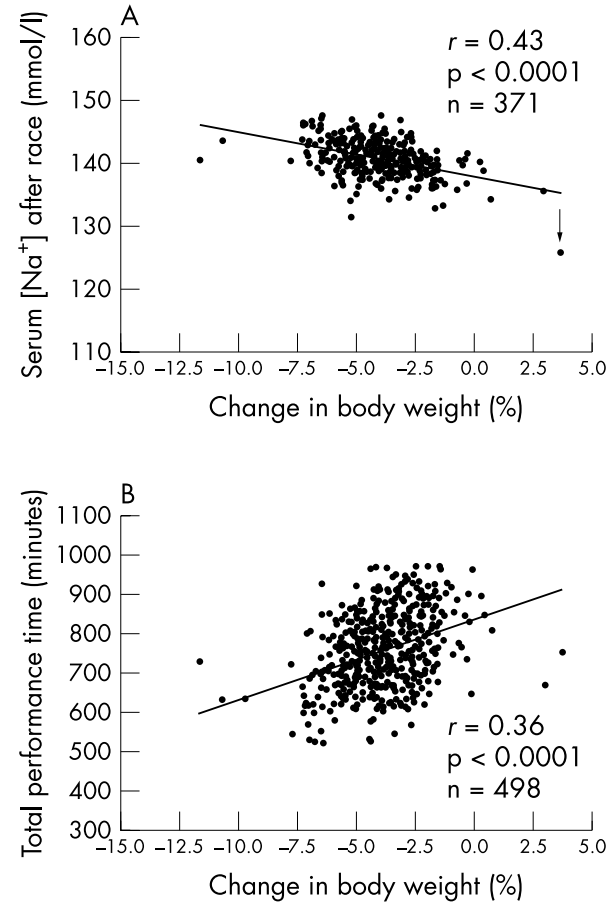

Figure 1 (A) There was a significant inverse correlation between the percentage weight loss during the race and $\left[\mathrm{Na}^{+}\right]$concentration after the race in 371 triathletes in the 2001 South African Ironman Triathlon so that those who lost the least weight had the lowest serum $\left[\mathrm{Na}^{+}\right]$after the race. Note that the athlete who gained the most weight during the race (arrowed) had the lowest serum $\left[\mathrm{Na}^{+}\right]$after the race and was the only athlete of 598 competitors to develop symptomatic hyponatraemia. (B) There was a significant linear relation between the degree of weight loss during the race and total performance time in 498 triathletes in the 2001 South African Ironman Triathlon such that those who lost the most weight finished the race in the shortest time.

athlete was admitted for the treatment of hyponatraemia on either the race day or the following day.

As a conservative drinking policy known to reduce the risk of hyponatraemia in the Ironman triathlon ${ }^{19}$ was also followed in this race, it is important to record that the incidence of medical diagnoses in competitors in this race was $8 \%$ (48 diagnoses; table 1 ), and that there was an inverse relation between total performance time in the race and the degree of weight loss during the race so that those who lost the most weight in the race, finished in the shorter times (fig 1B).

\section{DISCUSSION}

In this race, in which the changes in weight and serum $\left[\mathrm{Na}^{+}\right]$ of 371 participants (62\% of the total race finishers) in the Ironman triathlon were measured, only one $(0.2 \%$ of entrants) developed symptomatic hyponatraemia and completed the race with a serum $\left[\mathrm{Na}^{+}\right]$below $130 \mathrm{mmol} / \mathrm{l}$ (fig lA). This compares with reported incidences of biochemically and clinically diagnosed hyponatraemia of $27 \%{ }^{27}$ and $18 \%^{18}$ in the Hawaiian and New Zealand Ironman Triathlons respectively. Thus it appears that the incidence of hyponatraemia in the 2001 South African Ironman Triathlon was unusually low for a race of this kind.

As has now been repeatedly shown, ${ }^{13} 1718203637$ there was an inverse relation between serum $\left[\mathrm{Na}^{+}\right]$after the race and the degree of weight lost during it so that those who lost the least weight showed the largest reductions in race serum $\left[\mathrm{Na}^{+}\right]$(fig lA). Hence the most logical explanation for the near absence of cases of hyponatraemia in this Ironman triathlon must be that all but five triathletes $(0.83 \%$ of all 
Table 1 Medical diagnoses in 48 competitors treated in the medical tent at the finish of the 2001 South African Ironman Triathlon

\begin{tabular}{lll}
\hline Condition & $\begin{array}{l}\text { No of } \\
\text { athletes }\end{array}$ & $\begin{array}{l}\% \text { of } \\
\text { starters }\end{array}$ \\
\hline Muscle cramps & 15 & 2.5 \\
Gastrointestinal symptoms & 10 & 1.7 \\
Hypothermia & 9 & 1.5 \\
Exercise associated collapse & 8 & 1.3 \\
Lower back pain & 2 & 0.3 \\
Hypoglycaemia & 1 & 0.2 \\
Asthma & 1 & 0.2 \\
Corneal ulceration & 1 & 0.2 \\
Emotional distress & 1 & 0.2 \\
\hline
\end{tabular}

finishers) lost weight during the race, probably because all the entrants were advised to drink only $500-800 \mathrm{ml} / \mathrm{h}$ during the race and no more. Indeed, a previous study has shown that the incidence of hyponatraemia in the New Zealand Ironman Triathlon ${ }^{19}$ was dramatically reduced by the introduction of a more conservative drinking policy, in which the number of aid stations in the cycling and running legs was reduced. That same policy was adopted for this Ironman race. In contrast, competitors in a recent (1999) Hawaiian Ironman Triathlon were advised to drink at rates of 760$2000 \mathrm{ml} / \mathrm{h}$ depending on whether or not they classified themselves as light, moderate, or heavy sweaters. ${ }^{15}$ The Hawaiian Ironman Triathlon has traditionally experienced a high incidence of hyponatraemia. ${ }^{23-26}$

Thus as a result of the conservative drinking policy in the South African Ironman Triathlon, most finishers lost weight during the race and maintained their serum $\left[\mathrm{Na}^{+}\right]$. In contrast, the triathlete who gained the most weight during the race (arrowed in fig 1A) developed symptomatic hyponatraemia, thereby becoming the subject of this case report. That athlete's absolute weight gain of $3.8 \mathrm{~kg}$ approximates to an estimated total fluid gain of at least $5.0 \mathrm{~kg} .{ }^{17}{ }^{20}$ The approximate accuracy of this estimation is also suggested by the fluid excess that he excreted as urine (about 4.6 litres) during the first 18 hours of recovery. As respiratory and other sources of water loss were not measured during recovery, his total fluid excess at the finish of the race would have been greater than the 4.6 litres he passed as urine.

Hence these data confirm the finding that, with a single exception, all those athletes who have developed the symptomatic hyponatraemia of exercise and for whom the data are available have been substantially overhydrated at the time they sought medical care, ${ }^{121216-223738}$ with the most overhydrated athletes being the most symptomatic. This evidence refutes the conjecture that the symptomatic hyponatraemia of exercise always occurs in the presence of dehydration, as a result of large and uncompensated $\mathrm{Na}^{+}$ losses, ${ }^{23-27}$ or that $\mathrm{Na}^{+}$losses alone can cause this condition in persons who remain normally hydrated during exercise. ${ }^{8} 2930$

Indeed, the information collected from this athlete can be used to estimate the likely contribution made by any associated $\mathrm{Na}^{+}$deficit in the cause of this patient's hyponatraemia and so to address the accuracy of the conclusion that a $\mathrm{Na}^{+}$deficit alone can cause the symptomatic hyponatraemia of exercise in persons who remain normally hydrated during very prolonged exercise, for example, during a $90 \mathrm{~km}$ ultramarathon foot race. ${ }^{8}$

The magnitude of the $\mathrm{Na}^{+}$loss in sweat necessary to produce hyponatraemia has been estimated for athletes who drank sufficiently during a $90 \mathrm{~km}$ ultramarathon foot race so that they replaced all their sweat losses, but only with water, leaving an uncorrected $\mathrm{Na}^{+}$deficit. ${ }^{8}$ Using the premise that total body water is $62.9 \%$ of the body mass (or 44 litres in a $70 \mathrm{~kg}$ athlete) and the extracellular fluid volume is $39.8 \%$ of the total body water (or 17.5 litres in a $70 \mathrm{~kg}$ athlete), an athlete who completely replaced 8.6 litres of sweat during the $90 \mathrm{~km}$ race with pure water would develop $\mathrm{Na}^{+}$deficits of 215,430 , and $650 \mathrm{mmol}$ if his sweat $\left[\mathrm{Na}^{+}\right]$were respectively 25,50 , or $75 \mathrm{mmol} / \mathrm{l}$. The calculated serum $\left[\mathrm{Na}^{+}\right]$after the race for the three different sweat $\mathrm{Na}^{+}$concentrations would be respectively 135,130 , and $125 \mathrm{mmol} / \mathrm{l}$, only the latter of which might possibly cause symptomatic hyponatraemia (fig 1A).

These calculations generate two important conclusions. Firstly, these are exceptionally high sweat $\mathrm{Na}^{+}$concentrations for physically fit and heat acclimatised athletes. The inference is that $\mathrm{Na}^{+}$losses incurred by trained athletes during a $90 \mathrm{~km}$ foot race are unlikely to be sufficient to cause clinically relevant hyponatraemia, a conclusion that was also drawn in the paper that originally described the condition. ${ }^{1}$ This is an important acknowledgement that is missing from the overall conclusions of that publication ${ }^{8}$ as quoted in the introduction to this paper.

Secondly, these data show that, even if such pathological sweat $\mathrm{Na}^{+}$losses were indeed possible, they would still not be sufficient to lower the serum $\left[\mathrm{Na}^{+}\right]$to the mean value of $121 \mathrm{mmol} / \mathrm{l}$ measured in patients with symptomatic hyponatraemia, nor to the extremely low concentrations of 113$116 \mathrm{mmol} / \mathrm{l}$ measured in the most severe cases. ${ }^{1} 1012162139$ Hence the next conclusion of that paper ${ }^{8}$ is that a fluid excess of 5.1, 3.3, or 1.6 litres must be present to cause the serum $\left[\mathrm{Na}^{+}\right]$to fall to $121 \mathrm{mmol} / \mathrm{l}$ in athletes with the respective low, moderate, and high sweat $\mathrm{Na}^{+}$concentrations.

Hence these calculations disprove any theory that a $\mathrm{Na}^{+}$ deficit alone can cause the symptomatic hyponatraemia of exercise, except perhaps in the rare individual with pathologically high sweat $\left[\mathrm{Na}^{+}\right]$. That this modified conclusion must be correct is also shown by the clinical evidence that, as again confirmed by this report, with one exception, all 24 case studies of symptomatic hyponatraemia in which the relevant data have been measured, either gained weight during exercise or showed a positive fluid balance during recovery. ${ }^{15}$ Furthermore, the athletes who lost the most weight would be the most likely to have incurred the greatest $\mathrm{Na}^{+}$deficits as they had probably replaced the least fluid and $\mathrm{Na}^{+}$. Yet the most dehydrated athletes are always those with the highest serum $\left[\mathrm{Na}^{+}\right]$(fig lA). Nevertheless, this method of calculation ${ }^{8}$ can also be used to determine the extent to which a possible $\mathrm{Na}^{+}$deficit may have contributed to the hyponatraemia in the triathlete reported here.

This athlete had a starting body weight of $81.7 \mathrm{~kg}$ which corresponds to an estimated total body water of 51.4 litres and a total extracellular fluid volume of 20.5 litres according to these formulae. ${ }^{8}$ We do not know the serum $\left[\mathrm{Na}^{+}\right]$ immediately before the race, only the value measured three days earlier when the athlete was slightly lighter $(80 \mathrm{~kg})$. However, for the purposes of this calculation, we have presumed that his serum $\left[\mathrm{Na}^{+}\right]$of $143 \mathrm{mmol} / \mathrm{l}$ was the same on both days. This value equates to a total extracellular fluid $\mathrm{Na}^{+}$content of about $2932 \mathrm{mmol}$. As total body water expanded by at least 5 litres during the race, the corresponding increase in the extracellular fluid volume would have been 2.0 litres. Hence total $\mathrm{Na}^{+}$content of the extracellular fluid at the end of the race, when the serum $\left[\mathrm{Na}^{+}\right]$was $127 \mathrm{mmol} / \mathrm{l}$, would have been $2858 \mathrm{mmol}$, indicating a calculated loss of only $74 \mathrm{mmol} \mathrm{Na}{ }^{+}$during the race. This is substantially less than the amounts of 215-650 mmol estimated for a substantially shorter foot race $(90 \mathrm{~km}),{ }^{8}$ but is nevertheless of similar magnitude to the $\mathrm{Na}^{+}$deficits of $20-$ $300 \mathrm{mmol}$ estimated in other ultradistance athletes who have developed the symptomatic hyponatraemia of exercise..$^{12} 20$ 
The lower $\mathrm{Na}^{+}$deficit in this athlete can perhaps be explained either by the intake of $\mathrm{Na}^{+}$-containing foods and energy supplements during the race or as a result of a lower than expected sweat $\mathrm{Na}^{+}$concentration.

Hence these measurements and approximate calculations confirm that it is the fluid excess of 3-6 litres that causes this hyponatraemia, and that $\mathrm{Na}^{+}$supplementation is unlikely to prevent its development during exercise and might even exacerbate the symptoms in those who become overhydrated during exercise ${ }^{15}$ because $\mathrm{Na}^{+}$supplementation might increase whole body fluid retention, ${ }^{40}$ thereby theoretically exacerbating the cerebral oedema. Therefore prevention of this condition requires that athletes at risk drink less during exercise as already proposed in the original case reports. ${ }^{12}$ This case also proves that the ACSM proposals ${ }^{29} 30$ that athletes should increase their $\mathrm{Na}^{+}$intake before and during exercise to prevent this condition are not likely to be effective because, despite being profoundly hyponatraemic, this athlete finished with only a very small calculated $\mathrm{Na}^{+}$deficit ( $74 \mathrm{mmol})$. Even if he had not developed that magnitude of $\mathrm{Na}^{+}$deficit, his serum $\mathrm{Na}^{+}$concentration after the race would still have been $130 \mathrm{mmol} / \mathrm{l}$, as a result of the 2 litre expansion of his extracellular fluid volume.

Rather, athletes should be advised to "optimise rather than maximise fluid intake during extreme exercise". ${ }^{43}$ Indeed, as the only athlete to develop symptomatic hyponatraemia in this race was also the athlete who gained the most weight during the race (fig $1 \mathrm{~A}$ ), these data also prove that the only personal factor necessary to produce this condition is the practice of drinking "as much as possible" during exercise, ${ }^{4}$ that is, dipsomania. This has been confirmed by laboratory studies, especially that of Speedy et al, ${ }^{42}$ which showed that, in response to fluid overload at rest, subjects who had previously developed symptomatic hyponatraemia in the New Zealand Ironman Triathlon developed the same levels of hyponatraemia as did control runners who had completed the same race but without the development of hyponatraemia. Thus symptomatic hyponatraemia cannot develop without fluid overload; but the severity of the hyponatraemia will be determined by the degree to which the kidneys are able to correct the fluid imbalance and prevent a fluid overload.

An interesting clinical paradox also shown by this case report was that, despite profound fluid overload, the affected athlete passed little fluid during the first five hours after exercise. As serum [urea] and [creatinine] were unchanged, the absence of an appropriate diuresis was not due to a transient exercise induced renal failure of the kind previously described in an ultramarathon runner who lost $11 \%$ of her body weight during a $90 \mathrm{~km}$ foot race. $^{34}$ It is perhaps understandable why, in the absence of any urine production, it is a common error for the clinician to assume that the athlete is dehydrated and in need of intravenous fluid therapy. Yet providing intravenous fluids to an athlete with hyponatraemia could be potentially fatal. ${ }^{14} 1528$

Although there are no controlled clinical trials to determine the most effective treatment of exercise associated hyponatraemia, the experience of Ayus et $a l^{10}$ and Davis et $a l^{4}$ suggests that the use of slow intravenous $\mathrm{Na}^{+}$replacement may expedite recovery in those who are the most ill, as was also suggested in one of the original case reports. ${ }^{2}$ This athlete developed a diuresis only after he had received furosemide some five hours after he first presented in the medical tent at the race finish. The earlier use of furosemide in this case may have spared the need for hospital admission. In future, we will treat mild, uncomplicated cases of symptomatic hyponatraemia in those athletes who ignore our advice to drink only "ad libitum" during exercise, ${ }^{33}$ with oral $\mathrm{Na}^{+}$and intramuscular furosemide starting within 45 minutes of admission to the medical facility, provided that the athlete has yet to produce an adequate diuresis $(>600 \mathrm{ml} / \mathrm{h})$.

Finally, it is of interest that, even though a large number of athletes in the 2001 South African Ironman Triathlon finished with a weight loss greater than $5 \%$ (7\% of finishers; greatest individual weight loss $=-9 \mathrm{~kg}$ or $-12 \%$ of body weight; fig 1A), the incidence of medical diagnoses in that group was no greater than in the group who lost the least weight during the race (unpublished). Indeed, the incidence $(8 \%)$ of medical diagnoses (table 1 ) in competitors in this race was less that half the more usual incidences of between $17 \%^{18}$ and $17-20 \%^{27}$ in other Ironman triathlons. Furthermore, there was no apparent detrimental effect of higher levels of dehydration on finishing time in the race, because the triathletes who were the most dehydrated at the finish were also among the fastest (fig 1B). Nor was there any relation between higher levels of dehydration and changes in rectal temperature (unpublished) as also shown in our previous study of competitors in the 2000 South African Ironman Triathlon. ${ }^{36}$

In addition, all these "dehydrated" triathletes were released from the medical tent within 15-30 minutes of admission for blood sampling and without the need for intravenous fluid in a single instance. Yet the sole athlete who acted according to the popular "dehydration myth"'56914 15 28-303233 assuming that his fatigue could only be reversed by drinking "as much as possible", developed a profound fluid overload and was released from hospital only 29 hours after the race start, 17.5 hours after he had finished the race.

We again emphasise that the practice of self induced fluid overload (dipsomania) poses far greater health risks during very prolonged exercise than does "dehydration". 2831324142 Furthermore, to help athletes to understand the entirely preventable nature of this condition, it is proposed that, in future, "distance runners' dipsomania" should become the popular term, better to identify the single most important and avoidable factor causing the symptomatic hyponatraemia of exercise.

\section{ACKNOWLEDGEMENTS}

Funding for this study was provided by the South African Medical Research Council, the Harry Crossley and Nellie Atkinson Staff Research Funds of the University of Cape Town, Discovery Health, Bromor Foods, the National Research Foundation through the THRIP initiative, and the organisers of the South African Ironman Triathlon.

\section{Authors' affiliations}

T D Noakes, K Sharwood, M Collins, D R Perkins, UCT/MRC Research Unit for Exercise Science and Sports Medicine, Department of Human Biology, Faculty of Health Sciences, University of Cape Town and the Sports Science Institute of South Africa, Cape Town, South Africa

Correspondence to: Professor Noakes, UCT/MRC Research Unit for Exercise Science and Sports Medicine, Sport Science Institute of South Africa, PO Box 115, Newlands, 7725, South Africa; tdnoakes@sports. uct.ac.za

Accepted 20 May 2003

\section{REFERENCES}

1 Noakes TD, Goodwin N, Rayner BL, et al. Water intoxication: a possible complication during endurance exercise. Med Sci Sports Exerc 1985:7:370-5.

2 Frizzell RH, Lang GH, Lathan R. Hyponatremia and ultramarathon running JAMA 1986;255:772-4.

3 Speedy DB, Noakes TD, Schneider C. Exercise associated hyponatremia: a review. Emerg Med 2001;13:13-23.

4 Davis DP, Videen JS, Marino A, et al. Exercise-associated hyponatremia in marathon runners: a two-year experience. J Emerg Med 2001;21:47-57. 
5 Hew TD, Chorley JN, Cianca JC, et al. The incidence, risk factors and clinical manifestations of hyponatremia in marathon runners. Clin J Sport Med 2003; 13:41-7

6 Garigan TP, Ristedt DE. Death from hyponatremia as a result of acute water intoxication in an Army basic trainee. Mil Med 1999;164:234-8.

7 Montain SJ, Sawka MN, Wenger CB. Hyponatremia associated with exercise: risk factors and pathogenesis. Exerc Sports Sci Rev 2001;29:113-17.

8 Montain SJ, Lutzka WA, Sawka MN. Fluid replacement recommendations for training in hot weather. Mil Med 1999;164:502-8.

9 O'Brien KK, Montain SJ, Corr WP, et al. Hyponatremia associated with overhydration in U.S. Army trainees. Mil Med 2001;166:405-10.

10 Ayus JC, Varon J, Arieff Al. Hyponatremia, cerebral edema, and noncardiogenic pulmonary edema in marathon runners. Ann Intern Med 2000;132:711-14.

11 Smith S. Marathon runner's death linked to excessive fluid intake. New York Times, 13 Aug 2002

12 Irving RA, Noakes TD, Buck R, et al. Evaluation of renal function and fluid homeostasis during recovery from exercise induced hyponatremia. J Appl Physiol 1991;70:342-8

13 Noakes TD. The hyponatremia of exercise. Int J Sports Nutr 1992;2:205-28.

14 Noakes TD. Hyponatremia in distance athletes: pulling the IV on the 'dehydration myth'. Phys Sportsmed 2000;26:71-6.

15 Noakes TD. Hyponatremia in distance runners: fluid and sodium balance during exercise. Curr Sports Med Rep 2002;4:197-207.

16 Noakes TD, Norman RJ, Buck RH, et al. The incidence of hyponatremia during prolonged ultra-endurance exercise. Med Sci Sports Exerc 1990;22:165-70.

17 Speedy DB, Noakes TD, Kimber NE, et al. Fluid balance during and after an Ironman Triathlon. Clin J Sport Med 2001;11:44-50.

18 Speedy DB, Noakes TD, Rogers IR, et al. Hyponatremia in ultradistance triathletes. Med Sci Sports Exerc 1999;31:809-15.

19 Speedy DB, Rogers IR, Noakes TD, et al. Diagnosis and prevention of hyponatremia in an ultradistance triathlon. Clin J Sport Med 2000;10:52-8

20 Speedy DB, Rogers IR, Noakes TD, et al. Exercise-induced hyponatremia in ultradistance triathletes is caused by inappropriate fluid retention. Clin J Sport Med 2000; 10:272-8.

21 Speedy DB, Rogers IR, Safih S, et al. Hyponatremia and seizures in an ultradistance triathlete. J Emerg Med 2000;18:41-4.

22 Speedy DB, Noakes TD, Rogers IR, et al. A prospective study of exerciseassociated hyponatremia in two ultradistance triathletes. Clin J Sport Med 2000;10:136-41.

23 Hiller WDB. Dehydration and hyponatremia during triathlons. Med Sci Sports Exerc 1989;21(suppl):219-21.
24 Hiller DB, Laird RB. In: Roundtable. Hyponatremia in sport: symptoms and prevention, Sports Science Exchange 1993;4:3.

25 Hiller DB, O'Toole EE, Fortress RH, et al. Medical and physiological considerations in triathlons. Am J Sports Med 1987;15:164-9.

26 Hiller WDB, O'Toole ML, Massimino F, et al. Plasma electrolyte and glucose changes during the Hawaiian Ironman Triathlon. Med Sci Sports Exerc 1985; 17:S219.

27 O'Toole M, Douglas PM, Laird RH, et al. Fluid and electrolyte status in athletes receiving medical care at an ultradistance triathlon. Clin J Sport Med 1995:5:116-22.

28 Noakes TD. Hyponatremia or hype? Phys Sportsmed 2001;29:21-32.

29 American College of Sports Medicine. Position stand: heat and cold illnesses during distance running. Med Sci Sports Exerc 1996;28:i-x.

30 American College of Sports Medicine. Position stand: exercise and fluid replacement. Med Sci Sports Exerc 1996;28:i-vii.

31 Noakes TD. Fluid replacement during exercise. Exerc Sports Sci Rev 1993;21:297-330.

32 Noakes TD. Dehydration during exercise: what are the real dangers? Clin J Sport Med 1995:5:123-8.

33 Noakes TD. Fluid replacement during marathon running. Clin J Sport Med 2003;13:309-18.

34 Irving RA, Noakes TD, Raine RI, et al. Transient oliguria with renal tubular dysfunction after a $90 \mathrm{~km}$ running race. Med Sci Sports Exerc 1990;22:756-61.

35 Holtzhausen L-M, Noakes TD. Collapsed ultradistance athlete: proposed mechanisms and an approach to management. Clin J Sport Med 1997; 7:292-301

36 Sharwood K, Collins M, Goedecke J, et al. Weight changes, sodium levels, and performance in the South African Ironman Triathlon. Clin J Sport Med 2002;12:391-9.

37 Speedy DB, Faris JG, Hamlin M, et al. Hyponatremia and weight changes in an ultradistance triathlon. Clin J Sport Med 1997;7:180-4.

38 Flinn SD, Sherer RJ. Seizure after exercise in the heat: recognising lifethreatening hyponatremia. Phys Sportsmed 2000;28:61-7.

39 Clark JM, Gennari FJ. Encephalopathy due to severe hyponatremia in an ultramarathon runner. West J Med 1993;15:188-9.

40 Sanders B, Noakes TD, Dennis SC. Sodium replacement and fluid shifts during prolonged exercise in humans. Eur J Appl Physiol 2001;84:419-25.

41 Noakes TD, Wilson G, Gray DA, et al. Peak rates of diuresis in healthy humans during oral fluid overload. S Afr Med J 2001;91:852-7.

42 Speedy DB, Noakes TD, Boswell T, et al. Response to a fluid load in athletes with a history of exercise induced hyponatremia. Med Sci Sports Exerc $2001 ; 33: 1434-42$. 